Print ISSN: 1738-3110 / Online ISSN 2093-7717

http://dx.doi.org/10.15722/jds.15.11.201711.41

\title{
Capital Structure Adjustment in Korean Retail Firms
}

\author{
Sang-Su Kim*, Jeong-Hwan Lee**
}

Received: October 13, 2017. Revised: October 31, 2017. Accepted: November 15, 2017.

\section{Abstract}

Purpose - Capital structure adjustment costs influence the test of the standard trade-off theory of capital structure. We investigate whether there exist economically significant capital adjustment costs in the Korean retail industry.

Research design, data, and methodology - This paper adopts the model of Leary and Roberts(2005) to obtain the hazard rate of capital structure variations. The retail firms traded in the KOSPI and KOSDAQ markets are analyzed from 2000 to 2016.

Results - The empirical analysis shows infrequent capital structure adjustments in the Korean retail firms. The duration analysis emphasizes that the fixed adjustment cost plays an important role in the determination of capital structure adjustments for the Korean retail firms. Yet, even after taking account of infrequent capital structure adjustments, the trade off theory only weakly explains the capital structure variations of the Korean retail firms.

Conclusions - This paper confirms the existence of capital structure adjustment costs for the Korean retail firms. Our results argue for the significance of fixed adjustment costs in capital structure adjustments. Such emphasis on the fixed cost is inconsistent with the existing studies. The trade off theory does not successfully explain capital structure policy in the Korean retail firms even after considering adjustment costs.

Keywords: Capital Structure, Adjustment Costs, Retail Industry.

JEL Classifications: G30, G32.

\section{Introduction}

The standard trade-off theory of capital structure (Modigliani \& Miller, 1958) shows that firms have an optimal leverage ratio that balances the benefits and costs of debt outstanding. In other words, firms have a target leverage ratio and adjust instantaneously to the target for every period. It is noteworthy that the trade-off theory and following empirical analyses presumed costless adjustment of leverage ratio. In the absence of capital structure adjustment costs, the standard trade-off theory expects that firms continuously re-balance their capital structures to reach the target leverage ratio. Yet, in the presence of the adjustment costs, firms may not respond instantaneously to shocks that move them away from the target leverage ratios. If the capital structure adjustment costs exceed the benefits of targeting optimal leverages, firms may wait to recapitalize.

* Corresponding Author, Assistant Professor, Department of Economics, Korea National Open University, Korea.

Tel: +82-2-3668-4618. E-mail: sskim512@knou.ac.kr

** First Author, Assistant Professor, College of Economics and Finance, Hanyang University, Korea. Tel: +82-2-2220-1036.

E-mail: jeonglee@hanyang.ac.kr
By accounting for these adjustment costs, firms may not simply have an optimal leverage ratio but an optimal range of the ratio where they are inactive in terms of their financing policies.

Prior empirical studies verify the deviations from a firm's target leverage ratios. Fama and French(2002) show that firms' leverage ratios move slowly toward their target ones. In other words, their sample of the U.S. firms appear to take a long time to change their leverage to its target level or, loosely speaking, the optimal ratio. Moreover, Baker, and Wurgler(2002) show that historical effects to time equity issuances with high market valuations affect corporate capital structures persistently. Leary and Roberts(2005) also confirm that these slow re-balancing of leverage ratios are consistent with the existence of fixed and convex adjustment costs based on their duration analysis.

This paper performs the duration analysis of Leary and Roberts(2005) for the publicly listed Korean retail firms. Leary and Roberts(2005) employ a semi-parametric model of duration to estimate the hazard curve for the variety of decisions for firm level capital structure adjustments. Then they compare the shape of the estimated hazard curves in the U.S. firms with the simulated ones based on a different set of capital adjustment costs. This paper adopts their 
empirical model to examine the determinant of financing activities and the existence of leverage adjustment costs in the Korean retail industry.

This paper provides a number of interesting results. First of all, we confirm that the Korean retail firms are inactive with regard to their financial policies. In almost $66 \%$ of our sample's firm-quarter observations, the Korean retail firms either issue nor repurchase their own securities. This finding is in line with the results of Leary and Roberts(2005), which also support infrequent capital structure adjustment for the U.S. firms.

Next, our duration analysis shows that the estimated hazard rate curve monotonically increases. This finding stresses the significant role of fixed adjustment costs in capital structure policies. Such an importance of fixed cost is not well aligned with the results of Leary and Roberts (2005), which emphasize both of the fixed and convex adjustment costs components in capital structure re-balancing.

Finally, our duration model estimation results show that the standard trade-off theory does not explain the financing behavior of Korean firms very well. For all of financing activities related to leverage ratio, debt issuance/retirement, and equity issuance/repurchase decisions, the estimated coefficients on the firm's profitability are not well aligned with the prediction of the theory.

These findings contribute to the extant literature in a number of ways. Most of all, this paper, to our best knowledge, is the first study that conducts a duration analysis for the leverage ratio variation in the Korean retail industry. Furthermore, we highlight the importance of fixed adjustment costs in capital structure decision of the Korean retail firms, which is largely unexamined in the literature. The trade-off theory appears to have weak explanatory power in the financing policy of Korean retail firms unlike the results of Leary and Roberts(2005).

This paper proceeds as follows. Section 2 reviews the related literature. Section 3 depicts the econometric model. In section 4, we report the estimation results. Section 5 concludes.

\section{Related Literature}

The standard trade-off theory of capital structure presumes that firms have an optimal leverage ratio that perfectly balances the costs and benefits of debt financing (Modigliani \& Miller, 1958). The costs of debt financing refers to the potential loss for costly bankruptcy and agency conflicts. The benefits include the tax shields of interest payments and the relaxation of the free cash flow problem. A direct implication of the standard trade-off theory is the continuous re-balancing of leverage ratio. Over time, both the optimal and actual leverage ratios of firms may vary according to the variations in firm characteristics or market perturbations to the firm's value of equity and debt. If this change causes a firm's actual capital structure deviating from the target one, the trade-off theory predicts that the firm adjusts its debt to equity ratio to equate its actual leverage ratio with the optimal leverage one. Without adjustment costs, this response should be instantaneous.

Yet, there has been a growing body of literature investigating the significance of costs in capital structure adjustment on a firm's optimal leverage targeting. Fischer et al.(1989) theoretically argue that even a minor cost of recapitalization may results in long periods of inactivity of financial decisions. The theory implies that leverage ratio will be persistent; firms may not always respond to shocks that may affect their optimal debt to equity ratios. Accordingly, the observed leverage ratio is a noisy proxy of corporate financial policy that one may look elsewhere to examine the motivation behind corporate financing decisions.

Furthermore, Altinkilic and Hansen(2000) argue the significance of direct financing costs in debt and equity issuances. They empirically estimate equity and debt floatation cost functions and find the significant costs components, which may change the firm's capital structure policy substantially. Their findings are well aligned with the SEC rule 10b-18, which regulates the size and frequency of the financing transactions(see Cook et al., 2003).

This paper is most closely related with the analysis of Leary and Roberts(2005). They empirically test the trade-off theory of capital structure, allowing for costly capital structure adjustments. Their empirical results confirm that the financing behavior of U.S. firms is consistent with the trade-off theory if the effect of capital adjustment costs are considered. Their adoption of duration model also clarifies the distinctive implications of fixed, proportional and convex adjustment costs on the dynamic change of a firm's leverage ratio. To be specific, their simulation analysis argues that under the fixed cost of capital structure adjustment, the hazard rate of financing activity is increasing in time; under the linear cost of capital structure adjustment, the hazard curve is downsloping; under a fixed plus a weakly convex adjustment costs, the hazard curve tends to be moderately downward-sloping.

Testing leverage adjustment and leverage targeting behaviors are also related to previous empirical work that documents mean reversion in leverage such as Jalilvand and Harris(1984), and Fama and French(2002). Infrequent adjustment explains why the rate at which leverage reverts to its target one is often characterized as slow. Because firms do not re-balance every period, shocks to leverage may have long-lasting effects despite trade-off behavior.

Infrequent leverage adjustment is also related to the market timing literature of capital structure such as Baker and Wurgler(2002), and Welch(2004). These papers argue that because leverage is unresponsive to various economic shocks, the standard trade-off theory does not describe the 
corporate financial policy appropriately. Leary and Roberts (2005) argue that the infrequent leverage adjustment leads to persistent behavior of leverage as opposed to this literature.

The discontinuous re-balancing of capital structure is related to the existing survey evidence as well. The representative example is Graham and Harvey(2001). Their survey analysis shows that managers are concerned with the benefits and costs of debt financing(e.g., credit ratings) and largely have a range of target leverage ratio rather than an optimal ratio.

From a broad perspective, this paper is associated with the extant studies examining the effect of different adjustment costs on the dynamic behavior of corporations. This set of studies investigate the role of adjustment costs in inventory management(Harrison, 1985), cash management (Miller \& Orr, 1966), investment policy(Caballero \& Engle, 1999), and portfolio selection(Constantinides, 1986).

These related works are summarized in <Table $1>$.

$<$ Table 1> Related Literature

\begin{tabular}{|l|l|}
\hline \multicolumn{1}{|c|}{ Work } & \multicolumn{1}{|c|}{ Summary } \\
\hline Modigliani \& Miller (1958) & Propose target leverage ratio \\
\hline Fischer et al. (1989) & $\begin{array}{l}\text { Small adjustment cost drives } \\
\text { substantial deviation of leverage ratio } \\
\text { from the target }\end{array}$ \\
\hline $\begin{array}{l}\text { Altinkilic \& Hansen } \\
\text { (2000) }\end{array}$ & $\begin{array}{l}\text { Verify the existence of fixed and } \\
\text { convex floatation costs }\end{array}$ \\
\hline Leary \& Roberts (2005) & $\begin{array}{l}\text { Conduct the duration analysis as in } \\
\text { this paper }\end{array}$ \\
\hline Jalilvand \& Harris (1984) & $\begin{array}{l}\text { Slow adjustment of leverage ratio } \\
\text { toward the target. }\end{array}$ \\
\hline Fama \& French (2002) & $\begin{array}{l}\text { Persistency in capital structure } \\
\text { policies }\end{array}$ \\
\hline Baker \& Wurgler (2002) & \\
\hline Welch (2004) & $\begin{array}{l}\text { Survey results on the leverage } \\
\text { targeting }\end{array}$ \\
\hline Graham \& Harvey (200diustment of other \\
\hline Harrison (1985) & $\begin{array}{l}\text { Infrequent adjus } \\
\text { corporate policies }\end{array}$ \\
\hline Miller \& Orr (1966) & \\
\hline Caballero \& Engle (1999) & \\
\hline Constantinides (1986) & \\
\hline
\end{tabular}

\section{Econometric Model}

This paper employs the semi-parametric duration model of Leary and Roberts(2005). We denote $T$ as a random variable measuring the duration between capital structure adjustments. The period of financing inactivity between these adjustments is also denoted as spell. Then the hazard function is defined as follows:

$$
h(t)=\lim _{m \rightarrow 0} \frac{\operatorname{Pr}(t \leq T<t+m \mid T \geq t)}{m} .
$$

This hazard rate function points to the instantaneous change of likelihood at which a firm makes capital structure adjustments conditional on not having done so for time t. Informally, $h(t) m$ indicates the probability that this firm will make its capital structure adjustments in the next $\mathrm{m}$ units of time, conditional on not having made changes in its capital structure up to the time t. For example, the hazard rate function for equity issuances at $t=3$ gives the probability that a firm will issue equity in the next quarter, conditional on not having done so up to the last three quarters $(t=3)$. Thus, by modeling the time between a firm's financing activities such as debt issuance and repurchase, the hazard rate function describes the dynamic behavior of financing decisions.

Leary and Roberts(2005) parameterize this hazard rate function of the jth spell for firm $i$ as

$$
h_{i j}\left(t \mid \omega_{i}\right)=\omega_{i} h_{0}(t) \exp \left(x_{i j}(t)^{\prime} \beta\right)
$$

in which $\omega_{i}$ is a random component representing unobserved heterogeneity, $h_{0}(t)$ is a step function capturing the baseline hazard, $x_{i j}$ is a set of covariates, and $\beta$ is the corresponding coefficient vector to the covariates. As in line with the extant studies, it is presumed that the unobserved heterogeneity follows a gamma distribution. Estimate the model with the maximum likelihood method.

\section{Empirical Analysis}

\subsection{Data Description}

This paper examines the retail firms listed in the KOSPI and KOSDAQ markets from 2000 to 2016. The WISEfn database is employed to get quarterly financial statements and stock returns of the sample firms. The firm-quarter observations that miss the book asset value, short-term debt, long-term debt stock issuances, and stock repurchases are removed for our empirical examination.

To point out when a change in capital structure has occurred, this paper follows the method of Leary and Roberts(2005). An issuance or repurchase is labelled as occurred in a given quarter if the net change in debt or equity, normalized by the book value of asset at the end of the prior period, is greater than $5 \%$. This paper investigates four types of financing "spikes": debt issuances, debt retirements, equity issuances, and equity repurchases. Each of these spikes is represented by a binary variable indicating whether a spike has occurred or not for firm $i$ in period $t$. Except the case of equity repurchases, all of these binary 
variables adopt the $5 \%$ cutoff criterion. In case of equity repurchases, we employ a $1.25 \%$ cutoff to avoid missing smaller-sized repurchase programs in place during our sample period.

This work also examine two additional measures of capital structure adjustment decisions. In line with the extant literature, leverage increasing decisions and leverage decreasing decisions are also investigated as well. Because our focus is on corporate decisions that change leverage ratio, we require measures that isolate the effect of financial policies on leverage ratios. We refer to a leverage increase as net debt issuance less net equity issuance, divided by the book value of asset, greater than $5 \%$. We also denote a leverage decrease as net equity issuance less net debt issuance, divided by the book value of asset, larger than $5 \%$. As in the four basic financing spikes constructed above, the representation of leverage increase/decrease decision is achieved by using a binary variable.

Other firm characteristic variables are standardized by the book value of assets and defined as follows: Size is the ratio of sales for firm $i$ in quarter $t$ to the sum of sales for all firms in quarter $t$; MA/BA is the ratio between book assets minus book equity plus market equity and the book value of assets; CapEx $(t+1)$ refers to capital expenditures in quarter $t+1$; Cash is defined as cash and short-term marketable securities; DepAmort represents the depreciation and amortization in a given quarter; Tangibility is the ratio of fixed assets over book asset; Profitability is net operating income divided by the book asset value; Volatility takes the absolute value of the change in net income; Z-score is defined as the sum of 3.3 times earnings before interest and taxes (EBIT) plus sales plus 1.4 times retained earnings plus 1.2 times working capital, all of the components divided by the book asset values; Selling Expense refers to the selling expenses as a proportion of sales; Equity Return is the cumulative four-quarter stock return for the firm.

\subsection{Empirical Results}

$<$ Table 2> documents the summary statistics results for each type of capital structure adjustment decisions. The most striking result is that in $65 \%$ of the quarters in the Korean retail firms, no capital structure adjustment occurs in our sample periods. That is, a majority of the time firms are inactive with respect to their capital structure decisions. Yet, we are examining quarterly data, the rate of $66 \%$ of financing inactivity implies that the sample firms adjust their capital structures more than once a year, on average. As a result, we can conclude that the firms' financing activities are frequent but still far from continuous. Of course, this inactivity is consistent with the existence of capital structure adjustment costs, especially the fixed one.

$<$ Table 2> documents that the most common form of capital structure adjustments in the Korean retail firms is debt issuance, which takes account of over $18 \%$ of all capital structure adjustments. Debt issuance is followed by debt retirements $(13 \%)$, stock issuances $(5 \%)$, and stock repurchases $(2 \%)$. The table further shows that the leverage increase or leverage decrease decisions are generally more frequent than those four bias types of financing decisions. For instance, the frequency of leverage increase decision is greater thant that of all other four types of basic financing activities.

$<$ Table 2> also presents the information related to financing spell durations in the Korean retail firms. The median spell duration of each type of adjustment ranges from three quarters for the case of debt issuances to five quarters for the case of debt retirement. Both of the leverage increase and decrease choices have three quarter of median duration.

$<$ Table $3>$ provides summary statistics for each variable of our interests, after conducting several modifications to address outlier problems. First of all, we trim the lower and upper 1-percentile of the variable distribution. Next, we limit the leverage ratios of sample firms to lie in the unit interval. Last, we also limit the market-to-book ratio(MA/BA) to lie between 0 and 10, in line with Baker and Wurgler(2002). The table reports the mean, median and standard deviation of each variable.

$<$ Table 2> Summary Statistics: Financing Spikes

\begin{tabular}{|c|c|c|c|c|c|c|c|c|}
\hline & \multirow{2}{*}{ No. Adj } & \multirow{2}{*}{$\begin{array}{l}\text { Percentage } \\
\text { of periods }\end{array}$} & \multirow{2}{*}{$\begin{array}{c}\text { Right } \\
\text { Censored }\end{array}$} & \multirow{2}{*}{$\begin{array}{l}\text { Median } \\
\text { duration }\end{array}$} & \multicolumn{4}{|c|}{ Adj per Firm } \\
\hline & & & & & Mean & Min & Median & Max \\
\hline No adjustment & 1065 & $65.78 \%$ & 0 & 0 & 0 & 0 & 0 & 0 \\
\hline Debt Issue & 293 & $18.10 \%$ & 77 & 3 & 4.49 & 1 & 2.5 & 38 \\
\hline Debt Retirement & 214 & $13.22 \%$ & 79 & 4 & 5.43 & 1 & 3.75 & 34 \\
\hline Equity Issue & 76 & $4.69 \%$ & 93 & 2 & 4.01 & 1 & 2.5 & 24 \\
\hline Equity Repurchase & 34 & $2.10 \%$ & 99 & 5 & 10.88 & 1 & 4.5 & 51 \\
\hline Leverage Increase & 301 & $18.59 \%$ & 75 & 3 & 4.64 & 1 & 2.5 & 57 \\
\hline Leverage Decrease & 239 & $14.76 \%$ & 76 & 3 & 4.95 & 1 & 3 & 34 \\
\hline
\end{tabular}

Source: The Authors' Own Construction 
<Table 3> Summary Statistics: Determinant of Financing Variables

\begin{tabular}{|l|r|r|r|}
\hline & \multicolumn{1}{|c|}{ Median } & \multicolumn{1}{c|}{ Mean } & \multicolumn{1}{c|}{ Std } \\
\hline MA/BA & 1.04 & 1.19 & 0.59 \\
\hline Size & 0.5104 & 3.5238 & 7.9068 \\
\hline CapEx & 0.23 & 0.68 & 1.21 \\
\hline Cash & 11.36 & 15.71 & 15.51 \\
\hline DepAmort & 0.54 & 0.85 & 0.91 \\
\hline Tangibility & 32.23 & 35.78 & 27.40 \\
\hline Profitability & 1.59 & 1.40 & 5.23 \\
\hline Selling Expense & 26.62 & 39.40 & 37.09 \\
\hline Volatility & 1.37 & 3.58 & 7.82 \\
\hline Z-score & 0.67 & 0.63 & 1.06 \\
\hline Equity Return & -0.01 & 0.14 & 0.66 \\
\hline
\end{tabular}

Source: The Authors' Own Construction

$<$ Table 3> shows the distinctive characteristics of the retail firms compared to those of the entire Korean firms. In particular, the size of retail firms are far greater than that of Korean firms studied in the extant literature. Their selling expense is far greater than their counter part in the entire
Korean firms, which indicates the importance of selling costs in the Korean retail industry. In other words, the retail firms are generally large and their costs are important in their operations.

Next, we estimate the hazard rate curve for the six types of capital structure adjustments decisions illustrated above. Our estimation employs all of the firm characteristic variables defined above as independent variables. <Figure 1> depicts the estimates of our baseline hazard $h_{0}(t)$. Each panel of the figure shows the hazard rate against the quarter of interval for the six different types of financing activities; debt issuance, debt retirement, equity issuance, equity repurchase, leverage increase and leverage decrease decisions.

$<$ Figure 1> clearly points out that the hazard rate shows a monotonically increasing pattern for almost all cases. To be specific, except the case of equity issuance, all of the capital structure adjustment decisions in the Korean retail firms show generally increasing hazard rate curves. Only the stock issuance case is related to a hump shaped hazard rate curve in contrast to the other capital structure adjustments.

\section{Hazard Rate}
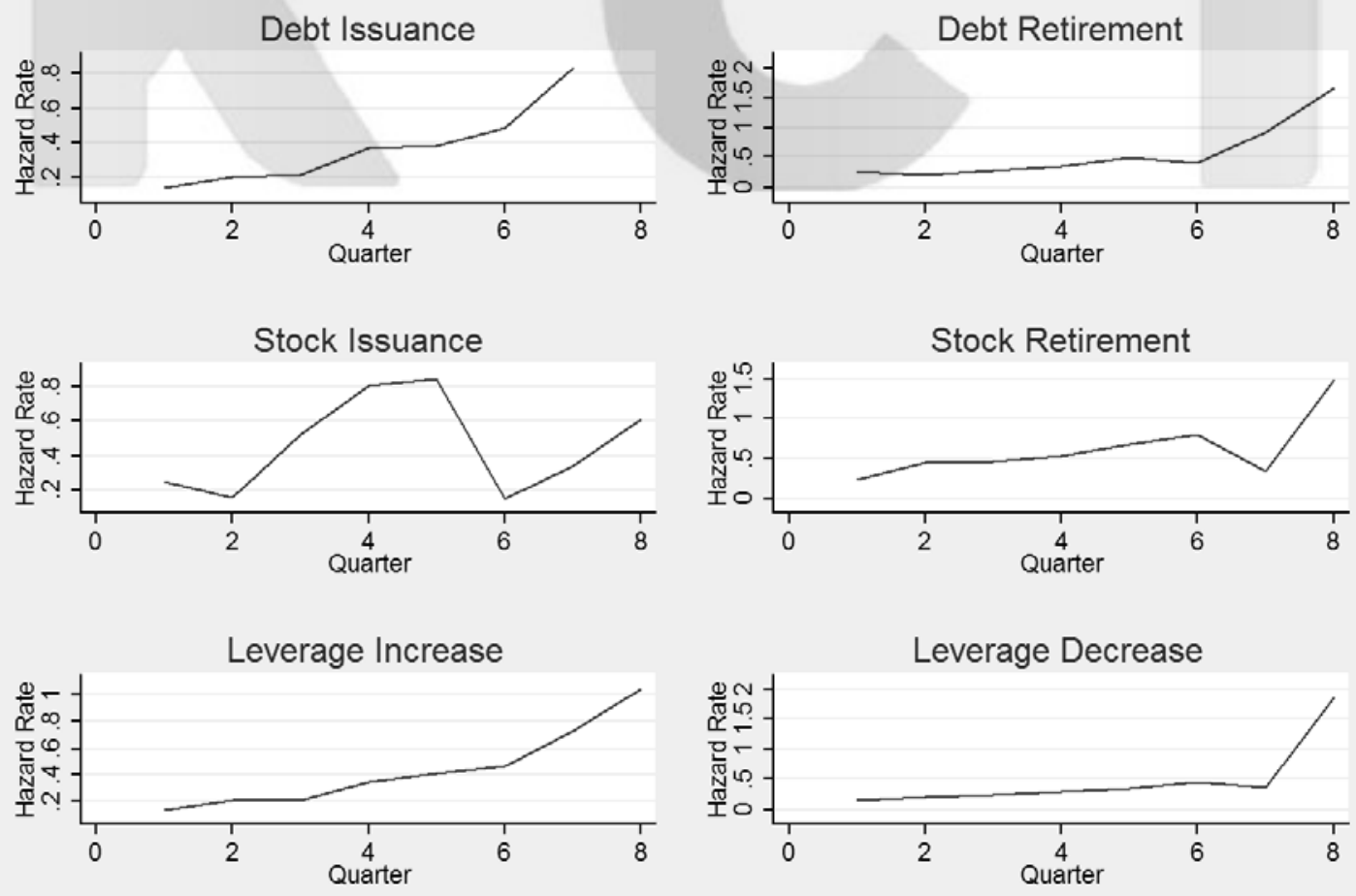

Source: The Authors' Own Construction

<Figure 1> Hazard Rate Curve 
This increasing hazard rate curve highlights the importance of fixed adjustment costs in the decision of capital structure adjustment for the Korean retail firms. The simulation analysis of Leary and Roberts(2005) argues that the hazard rate is increasing in time in the presence of the fixed cost of adjustment. The result of <Figure $1>$ is exactly in line with the fixed adjustment cost case of Leary and Roberts(2005).

This finding is inconsistent with the empirical evidence of Leary and Roberts(2005) for the publicly traded U.S. firms. They show slowly decreasing hazard rates for almost all capital adjustment decisions. Their simulation analysis shows that this slowly decreasing curve is in line with the existence of fixed and moderate convex adjustment costs in capital structure adjustment. Yet, our estimation shows an increasing hazard rate curve, which argues for the significance of fixed adjustment cost component for the dynamic change of capital structure in Korean retail firms.

We now turn to examine the determinant of financing spikes. <Table $4>$ reports the estimates of the covariate coefficients $(\beta)$ in the leverage increase/decrease decisions. It reports our estimates for the two leverage adjustment spells(leverage increase and leverage decrease). The corresponding $t$-values are reported in parenthesis. The Hazard Impact values are documented as well. The mark of ${ }^{*},{ }^{* *}$, and, ${ }^{* *}$ represent the statistical significance at $90 \%$, $95 \%$ and $99 \%$ levels, respectively.

The interpretation of the coefficients is aided by thois value of Hazard Impact $(\mathrm{HI})$. The Hazard Impact transforms the parameters in the following way:

$$
H I=(\exp (\beta)-1) \times 100 .
$$

The value of Hazard Impact provides the percentage change in the expected hazard rate for a one unit increase in the corresponding independent variable. For instance, if the hazard impact is estimated -0.0070 in equity issuance, an increase in the corresponding variable by $1 \%(1$ unit) decreases the likelihood of a equity issuance, conditional on not having issued equity up to that point of the time by $0.80 \%$.

$<$ Table 4> shows that the trade-off theory prediction does not apply well for the decision of leverage increase/ decrease. The profitability of a firm is negatively related to both of the leverage increase and decrease decisions inconsistent with the trade-off theory predictions. The coefficients are all statistically insignificant as well.

In the standard trade-off theory, a highly profitable firm tends to experience large tax benefits and low expected costs of financial distress, which implies a higher target leverage ratio. Accordingly, an increase in profitability raises the likelihood of leverage increase decisions. Conversely, a decrease in profitability raises the likelihood of leverage decrease decisions in the standard trade-off theory. <Table $3>$ weakly supports the negative correlation between the profitability and leverage decrease. It does not support the positive correlation between the profitability and leverage increase decisions.

<Table 4> Estimation Results: Leverage Variations

\begin{tabular}{|c|c|c|c|c|}
\hline Variable & \multicolumn{2}{|c|}{ Leverage Increase } & \multicolumn{2}{c|}{ Leverage Decrease } \\
\hline & Estimate & HI(\%) & Estimate & HI(\%) \\
\hline Size & -0.0016 & -0.1645 & 0.0118 & 1.1845 \\
& -0.1402 & & 0.8834 & \\
\hline MA/BA & 0.1708 & 18.6261 & 0.1487 & 16.0343 \\
& 1.2718 & & 0.7350 & \\
\hline CapEx & -0.0498 & -4.8565 & 0.0441 & 4.5080 \\
& -1.0530 & & 0.4330 & \\
\hline Cash & -0.0023 & -0.2294 & 0.0076 & 0.7583 \\
& -0.3909 & & 0.6860 & \\
\hline DepAmort & -0.1101 & -10.4276 & 0.0235 & 2.3757 \\
& -1.1450 & & 0.2206 & \\
\hline Tangibility & 0.0003 & 0.0347 & 0.0026 & 0.2608 \\
& 0.0172 & & 0.4356 & \\
\hline Profitability & -0.0174 & -1.7249 & -0.0098 & -0.9747 \\
& -0.9511 & & -0.5101 & \\
\hline Volatility & 0.0048 & 0.4804 & 0.0031 & 0.3080 \\
& 0.4157 & & 0.2400 & \\
\hline Z-score & 0.0271 & 2.7437 & -0.0420 & -4.1169 \\
& 0.2453 & & -0.3271 & \\
\hline Selling Expense & -0.0009 & -0.0888 & -0.0019 & -0.1861 \\
& -0.0194 & & -0.1386 & \\
\hline Equity Return & -0.1184 & -11.1685 & -0.1163 & -10.9798 \\
\hline & -1.1255 & & -0.9080 & \\
\hline
\end{tabular}

Source: The Authors' Own Construction

<Table 5> Estimation Results: Debt Issuance and Retirement

\begin{tabular}{|c|c|c|c|c|}
\hline Variable & \multicolumn{2}{|c|}{ Debt Issuance } & \multicolumn{2}{c|}{ Debt Retirement } \\
\hline & Estimate & HI(\%) & Estimate & HI(\%) \\
\hline Size & 0.0021 & 0.2144 & 0.0004 & 0.0372 \\
& 0.1371 & & 0.0207 & \\
\hline MA/BA & 0.1352 & 14.4798 & -0.0351 & -3.4523 \\
& 0.9495 & & -0.2056 & \\
\hline CapEx & -0.0347 & -3.4110 & 0.0491 & 5.0376 \\
& -0.6186 & & 0.4557 & \\
\hline Cash & 0.0003 & 0.0348 & 0.0035 & 0.3521 \\
& 0.0484 & & 0.4402 & \\
\hline DepAmort & -0.0807 & -7.7551 & -0.1401 & -13.0704 \\
& -0.8263 & & -1.3488 & \\
\hline Tangibility & -0.0007 & -0.0654 & -0.0002 & -0.0207 \\
& -0.0113 & & -0.0461 & \\
\hline Profitability & -0.0134 & -1.3350 & -0.0142 & -1.4057 \\
& -0.5919 & & -0.7144 & \\
\hline Volatility & 0.0047 & 0.4719 & -0.0009 & -0.0948 \\
& 0.3836 & & -0.0504 & \\
\hline Z-score & -0.0246 & -2.4336 & -0.0338 & -3.3210 \\
& -0.2773 & & -0.3112 & \\
\hline Selling Expense & -0.0017 & -0.1661 & -0.0021 & -0.2099 \\
& -0.1371 & & -0.3093 & \\
\hline Equity Return & -0.0488 & -4.7639 & -0.0869 & -8.3276 \\
& -0.3341 & & -1.0375 & \\
\hline
\end{tabular}

Source: The Authors' Own Construction 
$<$ Table 5> reports the estimates of the covariate coefficients $(\beta)$ in the debt issuance and retirement decisions. The table documents our estimates for the debt issuance and retirement spells. The corresponding t-values are documented in parenthesis. The Hazard Impact values are included as well. The sign of ${ }^{*},{ }^{* *}$, and, ${ }^{* * *}$ represent the statistical significance at $90 \%, 95 \%$ and $99 \%$ levels, respectively.

Similar to the results of $\langle$ Table 4$\rangle$, the estimation results in <Table 5> argue against the standard trade-off theory predictions. All coefficients are statistically insignificant. Furthermore, the profitability shows a negative correlation with the likelihood of debt issuance decisions, while the coefficient itself is not statistically significant. This result is not well aligned with the standard trade-off theory of capital structure predicting a positive correlation between profitability and debt issuance decisions.

<Table 6> Estimation Results: Equity Issuance and Repurchase

\begin{tabular}{|c|c|c|c|c|}
\hline Variable & \multicolumn{2}{|c|}{ Equity Issuance } & \multicolumn{2}{c|}{ Equity Retirement } \\
\hline & Estimate & HI(\%) & Estimate & HI(\%) \\
\hline Size & -0.0559 & -5.4349 & 0.0162 & 1.6333 \\
& -0.4071 & & 0.4335 & \\
\hline MA/BA & 0.2265 & 25.4203 & -0.5766 & -43.8174 \\
& 0.8786 & & -1.3169 & \\
\hline CapEx & -0.0409 & -4.0032 & -0.0630 & -6.1035 \\
& -0.7017 & & -0.2765 & \\
\hline Cash & 0.0033 & 0.3350 & -0.0035 & -0.3523 \\
& 0.1445 & & -0.2288 & \\
\hline DepAmort & -0.0952 & -9.0769 & -0.1052 & -9.9880 \\
& -0.4915 & & -0.2254 & \\
\hline Tangibility & 0.0066 & 0.6589 & -0.0194 & -1.9205 \\
& 0.2328 & & -0.5416 & \\
\hline Profitability & 0.0008 & 0.0837 & -0.0457 & -4.4687 \\
& 0.0308 & & -0.7224 & \\
\hline Volatility & 0.0009 & 0.0937 & 0.1052 & 11.0959 \\
& 0.0495 & & 1.0780 & \\
\hline Z-score & -0.0035 & -0.3456 & 0.0409 & 4.1730 \\
& -0.0313 & & 0.1523 & \\
\hline Selling Expense & 0.0025 & 0.2471 & -0.0061 & -0.6076 \\
& 0.3742 & & -0.2316 & \\
\hline Equity Return & -0.0731 & -7.0492 & 0.0176 & 1.7770 \\
& -0.2694 & & 0.0460 & \\
\hline
\end{tabular}

Source: The Authors' Own Construction

In <Table 6>, we document the estimation results for the covariate coefficients $(\beta)$ in the equity issuance and repurchase decisions. <Table $6>$ documents our duration model estimates for the equity issuance and repurchase spells. The corresponding t-values are reported in parenthesis as well. The Hazard Impact values are also included. The mark of ${ }^{*},{ }^{* *}$, and, ${ }^{* * *}$ represent the statistical significance at $90 \%, 95 \%$ and $99 \%$ levels, respectively.
Similar to the results of the previous tables investigating leverage ratio and debt issuance policy. the estimation results in <Table 6> does not support the standard trade-off theory predictions. The profitability shows a positive correlation with the likelihood of equity issuance decisions, while the coefficient itself is not significant. The profitability even shows a negative relationship with equity repurchase decisions. Both of the signs are not well aligned with the standard trade-off theory of capital structure predicting a negative(positive) correlation between equity issuance (repurchase) decisions.

The estimation results of our duration model do not support the standard trade-off theory prediction regardless of the selection of financing policies. In other words, the trade-off theory does not explain the financing behavior in Korean retail firms well. This finding is inconsistent with the U.S. evidence of Leary and Roberts(2005); they argue the U.S. firm support the standard trade-off theory of capital structure.

\section{Concluding Remarks}

\subsection{Summary}

We investigate the capital structure adjustment of the Korean retail firms. The capital structure adjustment is an important factor affecting the leverage targeting behavior predicted by the standard trade-off theory(Modigliani \& Miller, 1958). For this purpose, this paper adopts the semiparametric duration model of Leary and Roberts(2005). By using the duration model, we analyze the quarterly data from 2000 and 2016 for the publicly traded Korean retail firms.

Our main findings can be summarized as follows. Most of all, the Korean retail firms are generally inert with regard to their financing policies. In almost $66 \%$ of the sample firm-quarter observations, the Korean retail firms neither issue nor repurchase their own equity and debt. Such an infrequent capital structure adjustment is in line with the empirical evidence for the U.S. firms. Next, our duration analysis argues that the estimated hazard rate curve monotonically increases. This increasing curve highlights the significant role of fixed adjustment costs in the dynamics of capital structure variation. Yet, this finding is not well aligned with the U.S. evidence, arguing for the importance of the fixed and convex adjustment cost altogether. Finally, our empirical analysis shows that the trade-off theory does not explain the financing behavior of Korean retail firms very well. Especially, the coefficient on profitability in our duration analysis is not well explained by the standard trade-off theory. This inconsistency with the standard trade off theory also differs from the U.S. evidence. 


\subsection{Implications}

Our findings contribute to the extant literature in a number of aspects. This paper, to our best knowledge, is the first study conducting the duration analysis for the capital structure policy in the Korean retail industry. We also highlight the importance of fixed adjustment costs in capital structure decision of the Korean retail firms, which is largely unexamined in the extant literature as well. Our findings also argue that the trade-off theory appears to have weak explanatory power in the financing policy of Korean retail firms.

\subsection{Future Research}

While this paper emphasizes the role of fixed capital adjustment costs component in a firm's financing policy decisions, this work does not directly address other component of costs such as the proportional or convex capital adjustment costs. As in Altınkılıç and Hansen(2000), it seems necessary to investigate whether other adjustment costs are significant or not by using floatation costs data directly. We leave this topic for future researches.

\section{References}

Abdisalan, M., \& Isse Abdikadir, M. (2016). The Impact of Financial Management Practices on Growth of Small and Medium Enterprise in MOGADISHU. East Asian Journal of Business Economics, 4(3), 25-30.

Altınkılıç, O., \& Hansen, R. S. (2000). Are there economies of scale in underwriting fees? Evidence of rising external financing costs. Review of Financial Studies, 13(1), 191-218.

Baker, M., \& Wurgler, J. (2002). Market timing and capital structure. The Journal of Finance, 57(1), 1-32.

Caballero, R. J., \& Engel, E. M. (1999). Explaining investment dynamics in US manufacturing: $A$ generalized (S, s) approach. Econometrica, 67(4), 783-826.

Constantinides, G. M. (1986). Capital market equilibrium with transaction costs. Journal of political Economy, 94(4), 842-862.

Cook, D. O., Krigman, L., \& Leach, J. C. (2004). On the timing and execution of open market repurchases. Review of Financial Studies, 17(2), 463-498.

Fama, E. F., \& French, K. R. (2002). Testing trade-off and pecking order predictions about dividends and debt. Review of Financial Studies, 15(1), 1-33.

Fischer, E. O., Heinkel, R., \& Zechner, J. (1989). Dynamic capital structure choice: Theory and tests. The Journal of Finance, 44(1), 19-40.

Graham, J. R., \& Harvey, C. R. (2001). The theory and practice of corporate finance: Evidence from the field. Journal of financial economics, 60(2), 187-243.

Harrison, J. (1985). Brownian Motion and Stochastic Flow Systems. Probability and Mathematical Statistics. New York: John Wiley and Sons.

Jalilvand, A., \& Harris, R. S. (1984). Corporate behavior in adjusting to capital structure and dividend targets: An econometric study. The Journal of Finance, 39(1), 127-145.

Kim, S. S., \& Lee, J. H. (2016). The Marginal Value of Cash and Agency Conflicts in Korean Firms. The Journal of Asian Finance, Economics and Business, 3(4), 5-16.

Leary, M. T., \& Roberts, M. R. (2005). Do firms rebalance their capital structures?. The Journal of Finance, 60(6), 2575-2619.

Modigliani, F., \& Miller, M. H. (1958). The cost of capital, corporation finance and the theory of investment. The American economic review, 48(3), 261-297.

Miller, M. H., \& Orr, D. (1966). A Model of the Demand for Money by Firms. The Quarterly journal of economics, 80(3), 413-435.

Muhammad, H., Shah, B., \& UI Islam, Z. (2014). The Impact of Capital Structure on Firm Performance: Evidence from Pakistan. Journal of Industrial Distribution \& Business, 5(2), 13-20.

Welch, I. (2004). Capital structure and stock returns. Journal of political economy, 112(1), 106-131. 